\title{
A REVIEW OF BAMBOO AS A REINFORCEMENT MATERIAL IN SLAB PANEL IN MODERN CONSTRUCTION
}

\author{
Prof. Atika Ingole \\ Department of Civil Engineering \\ JD college of engineering \\ Nagpur, Maharashtra, India \\ 1 \\ Mr. Vipul Bambode \\ Department of Civil Engineering \\ JD college of engineering \\ Nagpur, Maharashtra, India
}

\begin{abstract}
Concrete is the basic material which is used in all over world for construction. We used steel as a reinforcement material to gain tension but the steel is expensive and corrodes our structure. Bamboo is cheaper reinforcing material that can be used in concrete to reduce the cost of construction and it is easily available material through the world. Bamboo is natural, economical and lightweight material for reinforcement as compared to steel reinforcement in residential building. It is having required compression and tensile strength. The lastingness specific weight ratio of bamboo is 20 times quite that of steel. Bamboo has good water absorption capacity; it may cause structural failure and reduce the mechanical properties. We are going to compare the flexural strength of steel and bamboo to find optimum results.
\end{abstract}

Keywords - Bamboo strips, flexural strength, treated bamboo, grooved bamboo

\section{INTRODUCTION}

The reinforcing of concrete structures has been studied by using fibrous reinforcement materials. These fibrous reinforcements include synthetic and natural fiber. Besides synthetic fibers other materials such as steel, glass and carbon in fibrous form have been used as concrete reinforcement along with concrete. Although these conventional materials provide significant improvement in properties of concrete they are obtained from nonrenewable and unsustainable sources which makes them a costly building material. Considering the restrictions of those synthetic fibers the main target has been to use renewable and sustainable material. These are natural fibers which contains lignocellulose materials in their composition. There are many such materials exist within the nature which have the potential to be utilized in concrete and make concrete structures more

\author{
Ms. Sakshi Gawande \\ Department of Civil Engineering \\ JD college of engineering \\ Nagpur, Maharashtra, India \\ Mr. Ayush Khobragade \\ Department of Civil Engineering \\ JD College of engineering \\ Nagpur, Maharashtra, India
}

sustainable and ecofriendly. One such fiber which belongs to Gramineae is bamboo.

Conventional RC structures are made up of steel and concrete. This form of structures is built because of their ability to withstand high loads, ease in construction, durability, etc. Over the period of time especially, in last two decades, there is a tremendous increase in demand for housing and infrastructure and the majority of them is RC structures. To meet this requirement, the production rate of cement concrete), and BRC (bamboo reinforced concrete). The experimentation included a series of flexure tests performed using Flexural testing machine (FTM). The flexural performance of every slab panel under

\section{LITERATURE REVIEW}

Pankaj R Mali, D datta (2018) 1092-1100 is stated that conventional steel reinforcement is used to provide additional tensile strength and energy absorption capacity to concrete members. Bamboo-concrete Bond behavior was first studied through a series of pull-out tests. A complete 15 concrete slab panels were fabricated and tested as per Euro code EN-1448-5 (2006). The contribution of bamboo strips with respect to PCC in each of the BRC slab was around 1.5-2 times higher in increasing flexural strength at limited deflections and it was similar to those of conventional RCC slabs. The overall research showed that instead of using treated plain bamboo strip, the proposed grooved bamboo strip (2\%) used in concrete slab panels, improved flexural strength, energy absorption capacity, ductility and mode of failure (ductile) compared to that of PTBRC and RCC (0.3\%) slab panels.

Atul Agarwal, Bharadwaj Nanda, Damodar Maity (2014)610-617 this study is done on the feasibility of bamboo as reinforcement in concrete. Concrete is generally reinforced 


\section{International Journal of Engineering Applied Sciences and Technology, 2020 Vol. 4, Issue 9, ISSN No. 2455-2143, Pages 129-133 \\ Published Online January 2020 in IJEAST (http://www.ijeast.com)}

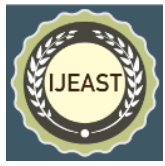

with the steel bars to negate its weak tension carrying capacity. After all, due to higher cost and non-renewability of steel, nowadays efforts are made to provide a low-cost feasible alternative by using locally available material. The feasibility for usage of bamboo as reinforcement in concrete is evaluated by the series of experimental investigations in the present study. First of all, tensile test of locally procured bamboo strips are conducted for evaluation of its ultimate strength and engineering properties. The axial compression and transverse loading tests are performed on plain, steel and bamboo reinforced columns to reveal the load carrying capacity, lateral deflection, and failure mode pattern. Also, two-point load test is performed on beams to study their behavior under bending. All these tests suggest that bamboo with proper treatment has the potential to substitute steel as reinforcement in beam and column members.

Concrete is the most widely used material in the building construction. Due to this, it is often reinforced with steel bars where in these bars provide the tensile strength to the concrete, but use of steel as reinforcing material has some disadvantage like higher cost and non-renewability of steels, also production of steel is responsible for a major source of greenhouse gas emission. Hence, attempts are being made by several researchers to provide a low-cost sustainable alternative of steel by using locally available material. Despite of the fact most of these studies yielded good results still bamboo has a clear advantage over other natural reinforcing materials. Bamboo is a fast growing wood like substance belongs to the grass family Phocaea. It reaches its optimum strength in just three to four years and attains the maturity in five years. The tensile strength of bamboo is very high and for some of its species the ultimate tensile strength is same as the yield strength of mild steel while the strength to specific weight ratio is sixfold greater than that of steel.

Hongwei Tan, Yingjun Ruan, Dongwei Yu (2011) the aim of this study is the material-based energy and carbon emissions over the life Cycle of bamboo-structure building ideal with innovative insulation technologies are analysed. While composing with typical brick-concrete building, the bamboo Structure building required less energy and emmits less $\mathrm{CO} 2$ to satisfy the identical function requirements. It indicate that there is potential To reduce $11.0 \%(18.5 \%)$ of the include energy (carbon) for the use of recycled content Building material the analysis provided an insight into the evaluation of the material based Energy and carbon emission over the life cycle of building.

Excessive consumption of fossil fuels leads to global warming of which the most influential factor is carbon. The bamboo structure residential building ideal is built to optimum into grate traditional architectural design concept with innovative Insulation technologies the building with standing fold roofing systems consist of living Eoom. The sustainable, hard and durable bamboo is used as supporting structure. It has high strength and environmental friendship to improve thermal insulation level of bamboo structure building vaccum insulation panel (VIP) is included between two mask modules to form a sand structure in the building before evaluating bamboo structure. Building general basis should be defined to qualify the difference between them. The method of life cycle assessment (LCA) is applied which judge environmental impact Associated with all the phase of building. The practical effect of the potential varies significantly on project management level and available technologies in the current Market.

Khosrow Ghavami (2005) this paper shows the results of some of the recent studies on the structure of bamboo. These studies show the initiation of bamboo composite behavior through the rule of mix. A brief summary concerning bamboo reinforced concrete beams, permanent shutter concrete slabs and columns are examined. Some recommendations for future studies are suggested with the hope that the newly developed material could contribute, on a large scale, to sustainable development without harming our orb. The present energy trouble causes by purposeless industrial growth has caused increasing concerns about managing the energy resources still available and about environmental degradation. There is an vigorous on-going research for non-polluting materials and manufacturing processes, which require less energy, and which can be used as a building material. The main motto of this paper is to present a incisive summary of the information about the range of material choices, which are locally available for manufacturing concrete structural elements, reinforced with bamboo.

In consequence of the consumers choosing industrialized products, among other effects, activities are terminated in rural areas or even in small towns, and renewable materials are wasted and causing permanent pollution. Thus, it becomes obvious to search ecological materials that can satisfy such fundamental requirements, Bamboo is one material, which will have a tremendous economic advantage, as it is found that it grows fully in just few months and the maximum mechanical resistance is reached in just few years. The required energy to manufacture $1 \mathrm{~m} 3$ per unit stress projected in practice for materials which are commonly used in civil construction, such as steel or concrete, has been compared with that of bamboo. It is necessary to spend 50 times much more energy for steel than we could consider for bamboo. The tensile strength of bamboo is very high and can reach up to $370 \mathrm{MPa}$. This makes bamboo as a good alternative to steel in tensile loading applications. Generally believed as bamboos are tress, but they are giant grasses, they belong to the family of the Bambusoideae. The bamboo Culm is in cylindrical shell, which is divided by transversal diaphragms at the nodes. Bamboo shells are orthotropic materials with high strength in the direction parallel to the fibers and strength perpendicular to the fibres respectively. 


\section{International Journal of Engineering Applied Sciences and Technology, 2020 Vol. 4, Issue 9, ISSN No. 2455-2143, Pages 129-133 \\ Published Online January 2020 in IJEAST (http://www.ijeast.com)}

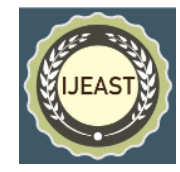

Alireza Javadian , Mateusz Wielopolski , Lan F.C.Smith , Dirk E Hebal bamboo is naturally growing material and easy affordable in many countries. The main aim of work is to find the bonding properties of a newly developed bamboo composite reinforcement in concrete through pull out test and various coatings are applied to determine bonding behaviour between concrete and newly developed bamboo-composite reinforcement .Still an epoxy baaed coating with sand particles could provide extra protection without lossing of bond strength. The bamboo composite bar develops a strong bond with concrete is cured and hardened. The average bond strength of bamboo-composite bars without coating and length of $200 \mathrm{~mm}$ was a good as water based epoxy coating with fine sand. Samples of water based epoxy with fine sand coating had and average bond strength of $3.65 \mathrm{MPa}$ and course sand was $3.61 \mathrm{MPa}$ and remaining $1.5 \%$ coating was course sand only.

The general aim of the sand coating was to determine whether the sand particles can help to increase bond strength between the bamboo composite bars, coating and concrete. The result base epoxy coating, True Grip EP, True Grip BP and expend coating it observes that adding sand to the coating either fine or course particles improves bonding between the corrected and the bamboo composite bars. When bamboo composite bars is pulled out of the concrete cylinder, friction due to interlocking mechanism between sand particles and without coating were similar to the bond strength of plain glass fibre reinforcement in normal strength concrete and still bond strength on only $80 \%$ of plain steel in normal grade concrete with same embedment length used in this study.

Lokendra Kaushal, Mr. Madan Chandra Maura the approach of their study is to reduce the cost of material by using bamboo stripes to provide reinforcement in concert beam in place of steel. It increases load carrying capacity, good reinforcement and environment friendly. It gives better flexibility, light weight, easy design, high tensile strength and the drawbacks are It possess low modules of elasticity compared to steel so it cannot prevent cracking tendency to absorb water affect the bond between concrete and bamboo. There is need for development of a simple design code for the application of bamboo as a construction material.

S V Rayadu, Akshay Randiwe, Ishwar Gupta (2017)245251 Vol 4 this paper stated that the bamboo is one of the oldest building material used by mankind. It is used by various construction works. Bamboo has good strength and durability. Now concrete is a widely used as construction material. It has various advantages such as, low cost durability, fire resistance etc. Reinforcement Cement Concrete plays very important role in construction. Due to increase of cost of steel and cement, cost of construction is increasing to control the cost of construction and promote the use of natural products the study is required be carried out. The highest and lowest failure load can recorded for the case of steel reinforcement and bamboo completely, in construction zone in tension zone.

The growth of science and technology is continuing search for improvement in infrastructure of world around us. It is great lesson for human study. It is estimated that a billion people on the world live in bamboo houses. The United States Navel Civil Engineering Laboratory (1966-2000) started the use of bamboo as concrete reinforcement ready structural lower. Bamboo is the most effective material in construction by the superior character of bamboo such as being physically powerful, tough and low cost material. The tensile strength of bamboo is $70 \mathrm{~N} / \mathrm{mm}$ about one third of that steel, with low ductility and total strain in steel of $12 \%$. In the present study, attempt has bet made to study the behavior of bamboo as reinforcement in concrete.

S. Jeeva Chidambaram, Sanjay Kumar studied the need of developing low cost building elements with the help of locally available materials. In rural areas the bamboo, are widely available and it can be used as replacement of common main steel. The experimental program conducted on testing 12 Ferro cement slab panels of size $470 \mathrm{~mm} \times 940 \mathrm{~mm}$ with the thickness of $40 \mathrm{~mm}$ and $50 \mathrm{~mm}$ each with 6 slabs. Out of these slabs, half i.e. 6 number with normal conventional mortar 1:3, while other half i.e. 6 after $15 \%$ cement replacement by fly ash, with bamboo grids as reinforcement were cast and cured under wet gunny bags for 28 days, then it is tested under uniformly distributed loading and the obtained results were compared with theoretical results. Test results show that the first crack load and experimental failure load is been same for both types of slabs. Also, both slabs had large ductility before final failure in flexure.

As the rapid increase in the demand for housing, the existing stock of conventional building materials like cement, steel etc. would fall short of the demand, if it is consumed excessively in order to provide basic infrastructure facilities, low cost building materials has become an important issue, As pee research it is suggested that Ferro cement can be an alternative material for roofing as it is more economical. Ferrocement is a composite product of cement, sand, wire mesh, skeletal steel and other admixtures. Based on the experimental study and as per experiments, it can be concluded that, the first crack loads and the ultimate loads for both slabs are found to be similar and are in good agreement with the observed values of the loads. The ultimate load is approximately twice than that of the first crack load. The contribution of bamboo strips with respect to mortar and wire mesh of the theoretical ultimate load capacity of the slab is about three times higher corresponding to the experimental ultimate load capacity. The system of Ferro cement slab panels involving the use of bamboo as replacement of steel and fly ash as partial replacement of cement can be used as roofing slab panels particularly for inaccessible roofing for low cost housing. This type of system will be useful for low cost housing in rural and sub urban areas. The benefits of this system are the utilization 


\section{International Journal of Engineering Applied Sciences and Technology, 2020 \\ Vol. 4, Issue 9, ISSN No. 2455-2143, Pages 129-133 \\ Published Online January 2020 in IJEAST (http://www.ijeast.com)}

of fly ash waste and bamboo, thus conserving the environment without hindering the structural integrity of the system. Also, Ferro cement and bamboo strips can be considered as one among the building materials that are less capital intensive and can be categorized under low cost roofing materials.

\section{ADVANTAGES}

- Bamboo is a non-polluting and does not have crusts or parts that can be considered waste.

- Different species of bamboo is used in constructions due to its physical characteristic example Guadua bamboo is suitable for all type of structure.

- Bamboo is a flexible and there hollow section make bamboo light weight material which is easy to handle, transport and store.

- Bamboo has an earthquake resistance capacity.

- Bamboo is used as a structural element, it is also used as another purpose in structure like flooring, water pipes, drainage, wall panelling and furniture.

- Bamboo is can be utilized for permanent and for temporary construction.

- Another advantages of building with bamboo is it can be used in combination with other type of material in construction like in reinforcement. We can replace of steel as a bamboo because bamboo give more tensile strength as compare to steel.

- Bamboo is cost effective than steel

\section{DISADVANTAGE}

- Moisture content directly affects the strength of bamboo.

- Bamboo has a less durable.

- Depend on the age of bamboo. Strength goes decreases as the increase in age.

- The number of benefits of bamboo outweighs its disadvantages.

\section{APPLICATION}

- The Bamboo is used in construction both internally and externally like for flooring, interior walls, exterior walls and also used for eco -friendly product.

- Bamboo has been used to build beautiful housing structures that are strong, durable and ability to withstand harsh condition.

- Bamboo stem is used for scaffolding during the construction of building and it is cheaper and more eco-friendly.

\section{CONCLUSION}

Water absorption, moisture content of bamboo can be controlled by using proper harvesting and preservation technique. By using Dendrocalmus Strictus we can attain adequate compressive strength. Bamboo used as a reinforcement which gives the better strength and flexibility to our structure and it is resist earthquake. Based on previous research paper it assurance that we can use bamboo as reinforcement it is most economical and cheaper than steel reinforced it is recommended to use in single story building. There is large scope for for designing multi story building using bamboo reinforcement in future.

\section{REFERENCE}

1. Mali R., Pankaj, and Datta D. (2018). "Experimental evaluation of bamboo reinforced concrete slab panels"( 1092-1100).

2. Tan Hongwei., Ruan Yingjun., and Yu Dongwei. (2011). "A future bamboo structure residential building prototype in china life cycle assessment of energy use and carbon emission."

3. Ghavami Khosrow.(2005). "Bamboo as reinforcement in structural concrete elements."(637649).

4. Bhonde Dinesh 1, Nagarnaik B. P., Parbat K. D., Waghe P. U. (2014). "Experimental Investigation of Bamboo Reinforced Concrete Slab" Volume03,Issue-01,(pp-128-131)

5. Rousset Patrick., Aguiar Clarissa., Labbé Nicole.,Michel-Jean.(2011).Commandré Enhancing the combustible properties of bamboo by torrefaction.(8225-8231).

6. Archila Hector., Kaminski Sebastian.,Trujillo David., Harries A. Kent.(2011). "Bamboo reinforced concrete: a critical review." 51-102

7. Sharma Bhavna., Gatóo Ana.,Bock Maximilian.(2015). "Michael Ramage Engineered bamboo for structural applications."(66-73)

8. Mansur A.M. and Azizt A.M.( 1983). "Study of bamboo-mesh reinforced cement composites" The International Journal of Cement Composites and Lightweight Concrete, Volume 5, Number 3

9. Tan T., Rahbar N., Allameh S., Kwofie S., Dissmore D., Ghavami K., Soboyejo O.W.(2011) "Mechanical properties of functionally graded hierarchical bamboo structures.'(3796-3803)

10. Trujillo E., Moesen M., Osorio L., A.W. Van Vuure, J. Ivens, I.(2014). Verpoest Bamboo fibres for reinforcement in composite materials: Strength Weibull analysis Composites: Part A

11. Shaha Darshil, Sharmab Bhavna, Michael H. (2018). "Ramagea Processing bamboo for structural composites: Influence of preservative treatments on 
surface and interface properties"International Journal of Adhesion and Adhesives 85 (15-22).

12. S.A.H. Roslan1, M.Z. Hassan2, Z.A. Rasid1, S.A. Zaki1, Y. Daud2, S. Aziz2, S. Sarip2 and Z. Ismail3(July-December 2015) "Mechanical properties of bamboo reinforced epoxy sandwich structure composites" Volume 12, pp. 2882-2892.

13. Wibow Ari, Wijatmikol Indradi, and Nainggolan Remayanti Christin 1, (2017) "Structural Behavior of Lightweight Bamboo Reinforced Concrete Slab with EPS Infill Panel."

14. Ghavami K.,( 2005). Bamboo as reinforcement in structural concrete elements, Cement and composites, 27,pp 637-649.

15. Glenn HE.,(1950).Bamboo Reinforcement in Portland Cement Concrete. Eng. Expt. Sta., Clemson College, Clemson, South Carolina, Eng. Bull. No. 4.

16. Irvine F. R.,(1961). Woody plants in Ghana, Oxford UK; Oxford University Press

17. Iyer S., (2002). Guidelines For Building BambooReinforced Masonry In earthquake-Prone Areas In India, MSc Thesis.

18. Faculty of the School of Architecture, University of Southern California.( p1-94).

19. Kankam CK, Odum-Ewuakye B.(1999).

"Structural behaviour of babadua reinforced concrete beams, Construction and Building Materials" 13, ( pp 187-193).

20. Kankam CK, Odum-Ewuakye B.,( 2006),

"Babadua reinforced two-way slabs subjected to concentrated loading, Construction and Building Materials" 20,( pp 279-285). 